Revista Brasileira de Farmacognosia Brazilian Journal of Pharmacognosy 21(3): 450-455, May./Jun. 2011

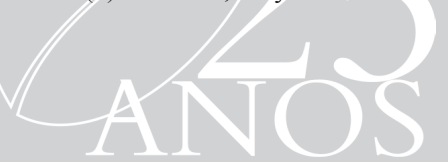

Article

Received 13 Jul 2010

Accepted 8 Oct 2010

Available online 1 Apr 2011

Keywords:

obesity

pancreatic lipase

Baccharis trimera

anti-nutrients

ISSN 0102-695X

doi: $10.1590 / \mathrm{S} 0102-695 \mathrm{X} 2011005000049$

\section{Inhibition of pancreatic lipase by extracts of Baccharis trimera: evaluation of antinutrients and effect on glycosidases}

\author{
Stefânia P. de Souza, ${ }^{*}, 1$ Luciana L. S. Pereira, ${ }^{1}$ Alline A. Souza, ${ }^{2}$ \\ Custódio D. dos Santos ${ }^{1}$
}

${ }^{I}$ Departamento de Química, Universidade Federal de Lavras, Brazil,

${ }^{2}$ Departamento de Nutrição, Universidade Federal de Alfenas, Brazil.

\begin{abstract}
In order to confirm the traditional use of Baccharis trimera (Less.) DC., Asteraceae, for the reduction of weight, plant extracts were evaluated on the activity of pancreatic lipase (PL), an enzyme responsible for hydrolysis of triacylglycerols in the diet for its subsequent absorption. The aqueous and infused extracts did not show inhibitory activity on the PL, the ethanol inhibited 16\% (66 ALI/g) and methanol extract inhibited 78\% (241 ALI/g). The methanol extract of $B$. trimera (MEB) was subjected to a wash with decreasing solvent polarity ( $n$-hexane, ethyl acetate and methanol) and only the methanol fraction inhibited the lipase by $72 \%(230 \mathrm{ALI} / \mathrm{g})$. We evaluated the MEB and infused inhibitory activity on the enzymes $\alpha$-amylase and $\alpha$ and $\beta$-glycosidases. The $\alpha$-amylase was not inhibited by any of the extracts, the enzyme $\alpha$-glucosidase was inhibited by both extracts in the same proportion $(46.9 \pm 0.1)$ and $\beta$-glucosidase was inhibited by $73 \%$ by the methanol extract and $65 \%$ by the infused. We also evaluated the presence of anti-nutrients. We detected the presence of saponins, polyphenols and trypsin inhibitors in the two samples. Tests performed in vivo can assess at which therapeutic concentration the presence of these anti-nutrients can be harmful to health.
\end{abstract}

\section{Introduction}

The potential of plants as a source of new drugs offers a wide field for scientific investigation, because of about 250,000 to 500,000 known species, a small percentage have already been phytochemically investigated and just a fraction have been evaluated as to their pharmacological potential (Rates, 2001). Even among the plants with traditional medicinal uses, there is still a high percentage that have not been the objects of study seeking proof of the effectiveness and safety of their uses (Cordell \& Colvard, 2005).

Baccharis trimera Less. (DC.), popularly known as "carqueja" (broom), belongs to the Asteraceae family and is an erect, branchy, glabrous subshrub, with up to $80 \mathrm{~cm}$ of height. Native to South America, it is cultivated mainly in Brazil, Argentina, Paraguay and in Uruguay (Ruiz et al., 2008). The tea is popularly used in the treatment of hepatic and digestive problems, for malaria, ulcers, diabetes, anemia, diarrhea, urinary inflammations, tonsillitis, worms, Hansen disease, weight reduction (Verdi et al., 2005; Biavatti et al., 2007; Agra et al., 2007, 2008), hypercholesterolemia, erectile dysfunction, feminine infertility and rheumatism, besides the use as an abortive agent (Alonso, 1998).

Biological assays aiming to attribute pharmacological actions for this species have been developed, evidencing anti-inflammatory and analgesic (Gené et al., 1996), antimutagenic (Nakasugi \& Komai, 1998), antiulcer (Dias et al., 2009), smooth muscle vasodilation (Torres et al., 2000), hypoglycemic (Matos \& Lorenzi, 2002; Barbosa-Filho et al., 2005), antiviral (Abad et al., 1999), gastroprotective (Gonzales et al., 2000), and antiarthritic effects (Coelho et al., 2004).

Obesity is becoming one of the largest threats to world health in this millennium, with more than one billion adults with excess weight (Harrold et al., 2003; Arbeeny, 2004). Discoveries towards the understanding of the molecular mechanisms that regulate body weight have provided potential opportunities for intervention with therapeutic ends and give renewed hope for the development of antiobesity drugs (Foster-Schubert \& Cummings, 2006). The market for those medicines is enormous and is responsible for 2 to $6 \%$ of the total health expenses, in various developed countries.

Currently, the potential of natural products for the treatment of obesity is still largely unexplored and 
can be an excellent alternative for the safe and effective development of antiobesity drugs (Bhutani et al., 2007). In this context, we investigated carqueja extracts as potential inhibitors of digestive enzymes (pancreatic lipase, $\alpha$-amylase and $\alpha$ - and $\beta$-glycosidases) and the presence of antinutrients within them.

\section{Material and Methods}

\section{Plant material}

Stems of Baccharis trimera Less. (DC.), Asteraceae, were collected in the municipal district of Lavras-MG, Brazil, and taken to the Biochemistry Laboratory of the Federal University of Lavras, where their processing was initiated. Its sample is deposited in the ESAL Herbarium, of the Biology Department of UFLA, under registration No. 873.

\section{Methanolic and ethanolic extract preparation}

The fresh plant material was washed and cut into fragments of approximately $1 \mathrm{~cm}^{2}$. Soon afterwards $1,238 \mathrm{~g}$ of this material was macerated in methanol for $48 \mathrm{~h}$. The mixture was filtered in cotton, obtaining a liquid phase that was dried in a rotary evaporator and lyophilizer. After the lyophilization, $105.78 \mathrm{~g}$ of a dark green powder was obtained that was stored in a freezer at $4{ }^{\circ} \mathrm{C}$. The ethanolic extract $\left(96.0^{\circ} \mathrm{G}\right)$ was prepared as described, however, $10.16 \mathrm{~g}$ of material soaked in ethanol for $48 \mathrm{~h}$ was used. After lyophilization, $0.768 \mathrm{~g}$ of a light green powder were obtained, that was stored in a freezer at $4^{\circ} \mathrm{C}$.

\section{Preparation of cold aqueous extract}

The fresh plant material was washed, fractioned into pieces of approximately $1 \mathrm{~cm}^{2}$ and triturated in a mortar and pestle. Soon afterwards, an aqueous extract was prepared in the proportion 1:10 $(\mathrm{p} / \mathrm{v})$, in an ice bath, using a horizontal agitator for $30 \mathrm{~min}$. After that time, the sample was centrifuged at $1700 \mathrm{~g}$, for $10 \mathrm{~min}$, at $4^{\circ} \mathrm{C}$.

\section{Preparation of carqueja infusion}

Stems of fresh carqueja were dried in a ventilated oven at $30{ }^{\circ} \mathrm{C}$, ground in knife mill and stored at room temperature. For the preparation of the infusion, $2 \mathrm{~g}$ of the powder were weighed and placed in infusion with $50 \mathrm{~mL}$ of boiling water for $10 \mathrm{~min}$ (conditions use by the population). After cooling, the tea was filtered in woven organza and stored at $4{ }^{\circ} \mathrm{C}$.

Obtention of enzymes
The enzymes were acquired in the form of industrialized standards: pig pancreatic lypase type II, Sigma; pig pancreatic $\alpha$-amylase type VI B, Sigma and pig pancreatic trypsin, Merck. The $\alpha$ and $\beta$-glycosidases were obtained from swine duodenum, supplied by the Animal Science Department, from animals destined to slaughter. The tissue was put in a mechanical homogenizer with water, filtrated in a $100 \mu \mathrm{m}$ nylon mesh and centrifuged at $1700 \mathrm{~g}$, for $10 \mathrm{~min}$, at $4{ }^{\circ} \mathrm{C}$. The sediment was collected and used as enzymatic extract.

Lipase, $\alpha$-amylase, $\alpha$ and $\beta$-glycosidase inhibition assay

The $\alpha$-amylase activity was determined using the methodology proposed by Noelting \& Bernfeld (1948). A $50 \mu \mathrm{L}$ sample and $50 \mu \mathrm{L}$ of $\alpha$-amylase enzyme were pre-incubated for $20 \mathrm{~min}$ in a water bath at 37 ${ }^{\circ} \mathrm{C}$. The starch substrate was prepared in $1 \%$ Tris 0.05 mol.L-1, pH 7.0 plus $\mathrm{NaCl} 38 \mathrm{mmol}^{-1} \mathrm{LaCl}_{2}$ and 0.1 mmol.L $\mathrm{L}^{-1}$. After addition of $100 \mu \mathrm{L}$ of the substrate, the mixture was incubated for 4 time periods. The reaction was stopped by adding $200 \mu \mathrm{L}$ of 3.5 dinitrosalicylic acid reagent and the product read in spectrophotometer at $540 \mathrm{~nm}$.

The $\alpha$-glycosidase activity of was determined by Kwon et al. (2006), using $p$-nitrophenyl- $\alpha$-Dglycopyranoside in $5 \mathrm{mM}$ citrate-phosphate buffer $0.1 \mathrm{M} \mathrm{pH} 7.0$ as substrate. In the trial, a $50 \mu \mathrm{L}$ sample and $100 \mu \mathrm{L}$ of enzyme were incubated in a water bath at $37{ }^{\circ} \mathrm{C}$ for 4 time periods after addition of $50 \mu \mathrm{L}$ of the substrate. The reaction was stopped by adding $1 \mathrm{~mL}$ of $0.05 \mathrm{M} \mathrm{NaOH}$, and the product read in spectrophotometer at $410 \mathrm{~nm}$. The $\beta$-glycosidase activity was determined in the same way, but we used $p$-nitrophenyl- $\beta$-D-glycopyranoside as substrate.

For the lipase activity, $100 \mathrm{~mL}$ of enzyme, $50 \mathrm{~mL}$ of sample extract and $50 \mathrm{~mL}$ of substrate $p$-nitrophenylpalmitate $8 \mathrm{mM}$ in Tris- $\mathrm{HCl} \mathrm{pH} 8.0$ containing $0.05 \mathrm{mM} 0.1 \%$ Triton-X100, were incubated for four time periods. The reaction was paralyzed by transferring the tubes to an ice bath and adding 1000 $\mathrm{mL}$ of Tris- $\mathrm{HCl} 0.05 \mathrm{mM}$. The $p$-nitrophenol of yellow color is read in spectrophotometer at $410 \mathrm{~nm}$ (Souza, 2009).

The inhibition of the enzymes were obtained from the determination of slopes of straight lines (Abs $\mathrm{x}$ time) for testing the activity of control enzymes (no sample) and enzymes+inhibitor. The slope of the results from the product formation speed per minute of reaction and the presence of inhibitor causes a decrease in its slope. From this slope the absorbance values were converted to mol of product using a standard curve. 
In an Erlenmeyer, $15.0 \mathrm{~g}$ of the methanolic extract were placed and $100 \mathrm{~mL}$ of hexane was added. The mixture was covered with aluminum foil and left under constant agitation for $30 \mathrm{~min}$. After that time, the mixture was put to decant the particles and the supernatant liquid filtered in cotton. That procedure was repeated four times. The hexane soluble fraction was concentrated in a rotary evaporator and lyophilizer. The residue insoluble in hexane was added to $100 \mathrm{~mL}$ of ethyl acetate and the procedure repeated. To the residue insoluble in ethyl acetate methanol $100 \mathrm{~mL}$ were added and the same procedure was undertaken as used with the other solvents. The masses obtained in each fraction were resuspended in water, in the proportion $1 \mathrm{~g}$ extract $/ 10 \mathrm{~mL}$ water, for conducting the lipase inhibition assays.

\section{Hemolytic activity}

The saponins were extracted from the methanol extract with a saline solution $(\mathrm{NaCl}$ $0.85 \mathrm{~g} 100 \mathrm{~mL}^{-1}$ ) buffered with $\mathrm{pH} 7.4$ phosphate buffer, with agitation at room temperature for $3 \mathrm{~h}$. This methodology allows to evaluate the potential of the extract in causing lesions in the cell plasma membrane, either by forming pores or their total collapse. The blood used was collected from healthy individuals and diluted in 30 volumes of saline $(\mathrm{NaCl}$ $\left.0.85 \%+\mathrm{CaCl}_{2} 10 \mathrm{mM}\right)$. The erythrocytes were washed twice in saline by centrifugation (5000 rpm/3 min) to reduce contamination in plasma and resuspended in saline to obtain an erythrocyte suspension. After an hour the hemolysis was verified (Barca et al., 1985).

\section{Antinutrients}

\section{Polyphenols}

The dosage of polyphenols in the carqueja extract was made according to the methodology of Folin-Denis, using tannic acid as a standard (Goldstein \& Swain, 1963; AOAC, 2005).

\section{Saponins}

The saponins of the methanolic extract and the carqueja infusion were extracted with ethanol, under agitation, for $1 \mathrm{~h}$, at room temperature. The saponin level was determined by the reaction of saponin with anise aldehyde and digitonin was used as a standard (Baccou et al., 1977).

\section{Inhibition of trypsin}

The trypsin inhibition was determined usinng $n$-benzoyl-DL-arginine- $p$-nitroanilide (BApNA), in Tris 0.05 mol. $\mathrm{L}^{-1}, \mathrm{pH} 8.2$, buffer as substrate. The activities were calculated according to Erlanger et al. (1961).

\section{Results and discussion}

The aqueous extract and the carqueja infusion did not inhibit PL in vitro. The ethanolic extract presented low inhibition (16\%). However, the methanolic extract considerably inhibited the PL activity by about $78 \%$ (Table 1 ).

Table 1. Pancreatic lipase activity in the presence of carqueja extracts.

\begin{tabular}{lcc}
\hline Extracts & \%Inibition* & Inhibited lipase activity (LAI/g)* \\
\hline Infusion & 0 & 0 \\
Aqueous & 0 & 0 \\
Ethanolic & $16 \pm 0.08$ & $66 \pm 0.10$ \\
methanolic & $78 \pm 0.34$ & $241 \pm 0.17$
\end{tabular}

*Average of three repetitions \pm standard deviation (LAI/g $=$ lipase activity inhibited per gram of plant).

The methanolic extract was fractioned with hexane, ethyl acetate and methanol, to evaluate the polarity characteristic of the inhibitors. The hexane fraction $(3.9 \%$ of the methanolic extract mass) and the ethyl acetate fraction $(42.6 \%$ of the methanolic extract mass) did not present inhibition on the lipase, while the methanolic fraction $(53.5 \%$ of the methanolic extract mass) (Table 2) inhibited the lipase at the same order of magnitude as the extract without fractioning (Table 1).

Table 2. Percentage of lipase inhibition after fractionation with solvents.

\begin{tabular}{lccc}
\hline Fraction & Mass obtained $(\mathrm{g})$ & \%Inibition* & $\begin{array}{c}\text { Lipase activity } \\
\text { inhibited } \\
(\mathrm{LAI} / \mathrm{g})^{*}\end{array}$ \\
\hline Hexane & $(\mathrm{LAI} / \mathrm{g})^{*}$ & 0 & 0 \\
Ethyl acetate & 6.226 & 0 & 0 \\
Methanol & 7.826 & $72 \pm 0.05$ & $230 \pm 0.2$
\end{tabular}

*Average of three repetitions \pm standard deviation (LAI/g $=$ lipase activity inhibited per gram of plant).

Many authors have isolated pancreatic lipase inhibitors from alcoholic extracts of plants. Among those works, that of Sharma et al. (2005) can be mentioned, who studied methanolic extracts of three plants, Eriochloa villosa (Thunb.) Kunth, Poaceae, Orixa japonica Thunb., Rutaceae, and Setaria italica (L.) P. Beauv., Poaceae, that exhibited strong antilipase activity in vitro (above 80\%). Furthermore, a lipase inhibitory molecule was isolated from the 
methanolic fraction of Salvia officinalis L., Lamiaceae, (Ninomiya et al., 2004) and a hypocholesterolemic effect was verified in mice that received doses of the Cymbopogon citratus (DC.) Stapf, Poaceae, ethanolic extract, evidencing the presence of lipase inhibitors (Agbafor \& Akubugwo, 2007). As for the methanolic extract of Ilex paraguariensis A. St.-Hil., Aquifoliaceae, a lipase inhibitor was also isolated (Sugimoto et al., 2009). Those works, as well as the results found in this study, suggest that the soluble organic compounds in methanol present some structural characteristic that have the capacity to inhibit pancreatic lipase.

Since the carqueja infusion is popularly used as a tool in antiobesity treatments and did not present inhibitory activity on the lipase, the inhibition of the infusion and of the lyophilized methanolic extract was evaluated on the activity of digestive glycosidases ( $\alpha$-amylase $\alpha$ and $\beta$-glycosidases). The results found showed inhibition on $\alpha$ and $\beta$-glycosidases, while the amylase was not inhibited by any of the extracts (Table 3 ). That inhibition caused by the carqueja infusion suggests that this can indeed be useful in the treatment of obesity, thus giving credit to the popular use of that plant.

That enzymatic inhibition of the glycosidases ( $\alpha$ and $\beta$ ) (Table 3 ) has been related to the presence of phenolic compounds in the plants, due to a structural characteristic common to all of them which is the presence of a hydroxylated aromatic ring, that resembles the sugar structures, natural substrates of the glycosidases (Kwon et al., 2006). The same does not happen with amylase, possibly for possessing a more specific bonding site than the glycosidases.

Table 3. Percentage of inhibition caused by infusion and methanolic extract of carqueja on glycolytic enzymes.

\begin{tabular}{lcc}
\hline \multirow{2}{*}{ Enzymes } & \multicolumn{2}{c}{ Inhibition\%* } \\
\cline { 2 - 3 } & Methanolic extract & Infusion \\
\hline$\alpha$-glycosidases & $47.3 \pm 0.5$ & $46.6 \pm 0.3$ \\
$\beta$-glycosidases & $73 \pm 0.23$ & $65 \pm 0.06$ \\
$\alpha$-amylase & 0 & 0 \\
\hline Average of three repetitions \pm standard deviation of the average.
\end{tabular}

Oliveira et al. (2005) evaluated the effect of the ethanolic, butanolic and aqueous extracts of carqueja on the glycemia of diabetic and non-diabetic mice and verified that only the aqueous fraction of Baccharis trimera (Less.) DC., Asteraceae, $(2000 \mathrm{mg} / \mathrm{kg}$, twice a day) reduced the glycemia after a treatment of seven days. Those can results be explained by the high inhibition of the $\beta$-glycosidases and $\alpha$-glycosidases enzymes responsible for the final digestion of the carbohydrates, impeding their absorption. However, as shown in this work, the aqueous extract and the methanolic extract presented inhibition on the $\alpha$ and $\beta$-glycosidases (Table 3), however, when the extract was obtained using methanol as solvent, the inhibition of the glycosidases continued being observed, besides the high pancreatic lipase inhibition, highly increasing the capacity of the methanolic extract in the antiobesity function.

Considering the current guidelines regarding the quality, effectiveness and safety of phytotherapic medicines, the evaluation of antinutrients present in the extract is indispensable (Table 4).

Inhibition of the trypsin was verified for the two samples, methanolic extract and infusion (Table 4). Trypsin inhibition causes a decrease of the protein digestibility. That inhibition can be unbeneficial for the organism, in vivo studies being necessary for the determination of that action.

The polyphenol level was similar between both (Table 4); the main class of secondary metabolites found in the species of the genus Baccharis is that of the polyphenols and many studies have been considering those substances as bioactive compounds because, in spite of possibly provoking health damage, many present an antioxidant or therapeutic capacity (Barcelos, 2004; Verdi et al., 2005).

Table 4. Levels of anti-nutrients in the methanolic extract and the carqueja infusion.

\begin{tabular}{|c|c|c|c|}
\hline \multicolumn{4}{|c|}{ Anti nutrients ${ }^{1}$} \\
\hline Extract & $\begin{array}{c}\text { Saponins } \\
\text { (g/100 g MS) }\end{array}$ & Trypsin (\%) & $\begin{array}{l}\text { Polyphenols } \\
\text { (mg tanic acid } \\
\text { /100 g MS) }\end{array}$ \\
\hline Infusion & $0.23 \pm 0.7$ & $57 \pm 0.2$ & $45.25 \pm 0.6^{*}$ \\
\hline Methanolic & $0.75 \pm 0.3$ & $71 \pm 0.7$ & $42.75 \pm 0.4 * *$ \\
\hline
\end{tabular}
coefficient 0.956 ; * correlation coefficient 0.99 ).

Saponins were found in a larger amount in the methanolic extract. The saponins possess lipophilic action, that facilitates the complexation of the saponins with steroids, proteins and phospholipids of the cell membranes, altering their permeability or causing their destruction, determining systemic manifestations, among which, hemolysis (Borella et al., 2006). Hemolysis was not detected in the assay conducted with the methanolic extract and the infusion, a result that can indicate low toxicity of the saponins present in the samples.

\section{Conclusion}

Given the in vitro verification of anti-nutrient presence in the extracts of carqueja, in vivo evaluations will be necessary so that the therapeutic concentration 
that will compose the phytotherapeutic will be insufficient to cause health damage.

The lyophilized methanolic extract, besides inhibiting the glycosidases, has high inhibitory action on the pancreatic lipase, being promising in the elaboration of a medicinal phytotherapeutic aid in the treatment of obesity.

\section{References}

Abad MJ, Bernejo P, Gonzáles E, Iglesias I, Irutzum A, Carrasco L 1999. Antiviral activity of bolivian plant extracts. Gen Pharmacol 32: 449-503.

Agbafor KN, Akubugwo EI 2007. Hypocholesterolaemic effect of ethanolic extract of fresh leaves of Cymbopogon citratus (lemongrass). Afr $J$ Biotechnol 6: 596-598.

Agra MF, França PF, Barbosa-Filho JM 2007. Synopsis of the plants known as medicinal and poisonous in northeast of Brazil. Rev Bras Farmacogn 17: 114140.

Agra MF, Silva KN, Basílio IJLD, França PF, BarbosaFilho JM 2008. Survey of medicinal plants used in the region northeast of Brazil. Rev Bras Farmacogn 18: 472-508.

Alonso JR 1998. Tratado de fitomedicina: bases clínicas $y$ farmacológicas. Buenos Aires: ISIS Ediciones S. R. L.

Arbeeny CM 2004. Addressing the unmet medical need for safe and effective weight loss therapies. Obes Res 12: 1191-1196.

Association of Official Analytical Chemists 2005. Official methods of analysis of Association of Official Analytical Chemists. 18. ed.

Baccou JC, Lambert F, Sauvaire Y 1977. Spectrophotometric method for the determination of total steroidal sapogenin. Analyst 102: 458-465.

Barbosa-Filho JM, Vasconcelos THC, Alencar AA, Batista LM, Oliveira RAG, Guedes DN, Falcão HS, Moura MD, Diniz MFFM, Modesto-Filho J 2005. Plants and their active constituents from South, Central, and North America with hypoglycemic activity. Rev Bras Farmacogn 15: 392-413.

Barca AMC De LA, Ochoa JL, Valencia ME 1985 Effect of extraction of a hemaglutinin on the nutritive value of Amaranthus leucocarpus seeds. J Food Sci 50: $1700-1702$

Barcelos MFP 2004. Substâncias tóxicas naturais em alimentos. Lavras: UFLA/FAEPE.

Bhutani KK, Birari R, Kapat K 2007 Potential anti-obesity and lipid lowering natural products: a review. Nat Prod Commun 2: 331-348.

Biavatti M, Marensi V, Leite SN, Reis A 2007. Ethnopharmacognostic survey on botanical compendia for potential cosmeceutic species from Atlantic Forest. Rev Bras Farmacogn 17: 640-653.

Borella JC, Duarte DP, Novaretti AAG, Menezes A Jr, França SC, Rufato CB, Santos PAS, Veneziani RCS, Lopes NP 2006. Variabilidade sazonal do teor de saponinas de Baccharis trimera (Less.)
DC. (Carqueja) e isolamento de flavona. Rev Bras Farmacogn 6: 557-561.

Coelho MGP, Reis PA, Gava VB, Marques PR, Gayer CR, Laranja GAT, Felzenswalb I, Sabino KCC 2004. Anti-arthritic effect and subacute toxicological evaluation of Baccharis genistelloides aqueous extract. Toxicol Lett 154: 69-80.

Cordell GA, Colvard MD 2005. Some thoughts on the future of ethnopharmacology. J Ethnopharmacol 100: 5-14.

Dias LFT, Melo ES, Hernandes LS, Bacchi EM 2009. Atividades antiúlcera e antioxidante Baccharis trimera (Less.) DC., Asteraceae. Rev Bras Farmacogn 19: 309-314.

Erlanger BF, Kokowsky N, Cohen W 1961. The preparation and properties of two new chromogenic substrates of trypsin. Arch Biochem Biophys 95: 271-278.

Foster-Schubert KE, Cummings DE 2006. Emerging therapeutic strategies for obesity. Endocr Rev 27: 779-793.

Gené RM, Cartañá C, Adzet T, Marin E, Parella T, Cañigueral S 1996. Anti-inflammatory and analgesic activity of Baccharis trimera: identification of its active constituents. Planta Med 62: 232-235.

Goldstein JL, Swain T 1963. Changes in tannins inripening fruits. Phytochemistry 2: 371-383.

Gonzales E, Iglesias I, Carretero E, Villar A 2000. Gastric cytoprotection of bolivian medicinal plants. J Ethnopharmacol 70: 329-333.

Harrold JA, Williams G, Wong S 2003. Neuroendocrine targets for the treatment of obesity: physiological roles and unrealized opportunities. Curr Med Chem Cent Nerv Syst 3: $141-155$.

Kwon YI, Apostolidis E, Shetty K 2006. Inhibitory potential of wine and tea against $\alpha$-glucosidase for management of hyperglycemia linked to type 2 diabetes. J Food Biochem 32: 15-31.

Matos FJA, Lorenzi H 2002. Plantas medicinais no Brasil: nativas e exóticas. Nova Odessa: Plantarum.

Nakasugi T, Komai K 1998. Antimutagens in the brazilian folk medicinal carqueja (Baccharis trimera Less). J Agric Food Chem 46: 25603564 .

Ninomiya K, Matsuda H, Shimoda H, Nishida N, Kasajima N, Yoshino T, Morikawa T, Yoshikawa M 2004. Carnosic acid, a new class of lipid absorption inhibitor from sage. Bioorg Med Chem Lett 14: 1943-1946.

Noelting G, Bernfeld P 1948 Sur les enzymes amylolytiques III-La $\beta$-amylase: dosage d'activité et contrôle de l'absence d'alphaamylase. Helv Chim Acta 31: 286-290.

Oliveira ACP, Endringer DC, Amorim LAS, Brandão MGL, Coelho MM 2005. Effect of the extracts and fractions of Baccharis trimera and Syzygium cumini on glycemia of diabetic and non-diabetic mice. J Ethnopharmacol 102: 465-469.

Rates SMK 2001. Plants as source of drugs. Toxicon 39: 
Inhibition of pancreatic lipase by extracts of Baccharis trimera: evaluation of antinutrients and effect on glycosidases Stefânia P. de Souza et al.

603-613.

Ruiz ALTG, Taffarello D, Souza VHS, Carvalho JE 2008. Farmacologia e toxicologia de Peumus boldus e Baccharis genistelloides. Rev Bras Farmacogn 18: 295-300.

Sharma N, Sharma VK, Seo SY 2005. Screening of some medicinal plants for anti-lipase activity. $J$ Ethnopharmacol 97: 453-456.

Souza SP 2009. Ação inibitória de extratos de plantas sobre lipase pancreática com ênfase em Baccharis trimera (Less.) DC. Lavras, 101 p. Dissertação de Mestrado, Departamento de Química, Universidade Federal de Lavras.

Sugimoto S, Nakamura S, Yamamoto S, Yamashita C, Oda Y, Matsuda H, Yoshikawa M 2009. Brazilian natural medicines. III. Structures of triterpene oligoglycosides and lipase inhibitors from Mate, leaves of Ilex paraguarienses. Biol Pharm Bull 57: 257-261.

Torres LMB, Gamberini MT, Roque NF, Landman MTL, Souccar C, Lapa AI 2000. Diterpene from Baccharis trimera with a relaxant effect on rat vascular smooth. Phytochemistry 55: 617-619.

Verdi LG, Brighente IMC, Pizzolatti MC 2005. Gênero Baccharis, Asteraceae: aspectos químicos, econômicos e biológicos. Quim Nova 28: 85-94.

\section{*Correspondence}

Stefânia P. de Souza

Departamento de Química, Universidade Federal de Lavras Caixa Postal 3037, 37200-000 Lavras-MG, Brazil santoscd@uflfla.br Tel. +552181006968 